992

H本機械学会論文集(B 編)

62 㶳 $595 \frac{1}{2}(19963)$

論文 No. 950959

\title{
数值解析による流体音の音源分布の解析*
}

\author{
古池 治 孝*1, 石 原国 彦*1 \\ 後 藤 知 伸*2, 高 野 泰 斉*2
}

\section{Analysis of Aeroacoustic Source Distribution by Means of Numerical Simulation}

Harutaka KOIKE, Kunihiko ISHIHARA.

Tomonobu GOTO and Yasunari TAKANO

\begin{abstract}
This study deals numerically with the aerodynamic sound radiated from the flow over a circular cylinder at a Reynolds number of $10^{3}$. The standard acoustic analogy method is applied. The incompressible time dependent two-dimensional flow around the cylinder is calculated by means of the finite difference method, then the variables are substituted into the approximate analytic soluion of a nonhomogeneous wave equation. The result of far-field sound calculation using a solution which Howe expresses as a volume integral form is compared with that using another one which Curle expresses as a surface integral form. Cood agreement is obtained between them. Howe's equation is used to investigate the sound source distribution in the flow field. The sign of the pressure fluctuation radiated from a small sound source region is opposite to those radiated from the neighboring ones. Most of the pressure fluctuations interfere and vanish as a consequence of volume integration. The remaider is observed as far field sound. It is shown that there are some regions which contribute more significantly to the sound generation than the other regions on average in time.
\end{abstract}

Key Words: Aerodynamic Acoustics, Computational Fluid I)ynamics, Finite Difference Method, Sound Source Analysis, Curle's Eqution, Howe's Equation, Far field Sound

\section{1. 緒 言}

近年、航空機、車両、自動車などの輸送機械や送風機 などの流体機械で発生する騒音問題の原因として、風 切り音などの流体音が大きな割合を占めるようになっ てきている。発生する音の大きさが速度のへき乗に比 例して大きくなるということが流体音の大きな特徴と しておげられるのて、、流れが低速の時には、振動音に かき消されていた流体音か、輖送機械の高速化、流体 機械の高性能化によって突出してきたものと考えられ る。この流体音の予湘を精度良く行うことができれば、 流体焉低減のための指針が得られ、各程機器の低駱 音化に大きく貢献するものと期侍される。

流体音予測には、Lighthill の音䚤アナロジー(1)の考 え方に従って、流れの数值解析 (CFD解析) と波動方 程式の近似解を組み合わせる方法が用いられる。波動 方程式の近似解としては、物体表面に働く力の時間勾

* 原稿受付 1995 年 6 月12 11

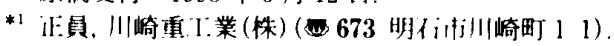

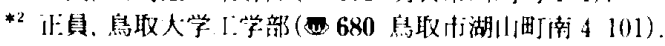

配と遠距離音埸の関係を与える Curle の式(2)がよく用 いられる。この式を 3 次元 CFD 解析結果と租み合わせ ると、実験とよく一致した結果が得られている(3)。ま た、2 次元 CFD 解析とCurle の式に基ついた相当音源 の解析(4)などもなされている。

一方、音の直接の発生源は渦運動に起因するものて あり、物体表面での王力変動は、その結果であるとい う考え方に基ついて、波動方程式の近似解に Howe の 式(5)が用いられることもある(6)。遠距嚄音場を求める のに、Curleの式では物体表面の積分を行うのに対し て、Howeの式では流れ場全体の棈分を行うため、数值 解析を行う際の積分領域の設定の問題、棈分点数の大 小による計算時間の問題などで、Curleの式がこれまで よく用いられてきたものと考えられる。しかし、流体 音の制御を考えるときには、流体の運動そのものと流 体音の関係を結びつけることのできる Howe の式の利 点を生かすことができると考えられる。

本研究では、円柱まわりの 2 次元 CFD 解析と Curle の式あるいは Howeの式を組み合わせて、カルマン渦 から放射される流体音の解析を行い、Curleの式による 
解析と Howe の式による解析の結果を比較する。さら に、Howeの式に基ついた音源分布の解析を行い、遠距 離音に対して時間平均的に音源として寄与する特定の 領域が存在することを明らかにする。

\section{2. 解析の方法}

2.1 流れの数值解析音は此縮性流体の中を伝播 するか、波長に比へてて十分小さい音源領域から放射さ れる遠距離音の場合、すなわち音源領域がコンパクト な場合、音源領域での流体の遇動は非正縮性流体のも のとして取り扱ってよいことが知られている(3).(7)。し たがって、本研究では円柱まわりの流れを非止縮性流 体として、差分法による解析を行う。

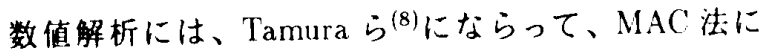
準じる方法を用いる。すなわち、連続の式と遇動方程 式を連立させて得られる化力 $p$ のポアソン方程式 (1) と運動方程式 (2) を連立し、時間発展させながら解く 方法である。

$$
\begin{aligned}
& \frac{1}{\rho_{0}} \nabla^{2} p=-\nabla \cdot(\mathbf{u} \cdot \nabla) \mathbf{u}-\frac{1}{\Delta t} D^{n}, \quad D=\nabla \cdot \mathbf{u} \\
& \frac{\partial \mathbf{u}}{\partial t}+(\mathbf{u} \cdot \nabla) \mathbf{u}=-\frac{1}{\rho_{0}} \nabla p+\nu \nabla^{2} \mathbf{u}
\end{aligned}
$$

$こ こ て ゙ 、 t は$ は時間、 $\mathbf{u}$ は速度ベクトル、 $\rho_{0}$ は密度、 $\nu$ は 動粘性係数である。また、 $\Delta t$ は時間刻み幅を、上添字 $n$ は時間ステップを示す。

対流項には 3 次精度の風上差分を用いる。たとえば、 格子点iにおける $u \partial u / \partial x$ は、格子間隔を $h$ とすると、

$$
\begin{array}{r}
\left(u \frac{\partial u}{\partial x}\right)_{i}=u_{i} \frac{-u_{i+2}+8 u_{i+1}-8 u_{i-1}+u_{i-2}}{12 h} \\
+\left|u_{i}\right| \frac{u_{i+2}-4 u_{i+1}+6 u_{i}-4 u_{i-1}+u_{i-2}}{4 h}
\end{array}
$$

となる。その他の項には中心差分を用いる。

時間発展については、式 (4)のように対流項を線形 化し、半陰的に計算をすすめる。

$$
\mathbf{u} \cdot \nabla \mathbf{u}=\mathbf{u}^{n+1} \cdot \nabla \mathbf{u}^{n+1} \simeq \mathbf{u}^{n} \cdot \nabla \mathbf{u}^{n+1}
$$

2.2 Curle の式静止流体中を伝わる密度変動 $\rho^{\prime}$ を、任意の定数 $c_{0}$ を使って非斉次波動方程式の形に表 した Lighthill 方程式 ${ }^{(1)}$ は、

$$
\left(\frac{\partial^{2}}{\partial t^{2}}-c_{0}^{2} \nabla^{2}\right) \rho^{\prime}=\frac{\partial^{2} T_{i j}}{\partial x_{i} \partial x_{j}}
$$

である。 $T_{i j}$ は、

$$
T_{i j}=\rho u_{i} u_{j}+\delta_{i j}\left(p^{\prime}-c_{0}^{2} \rho^{\prime}\right)-e_{i j}
$$

であり、Lighthillの乱流心ノテンソルと呼ばれる。ここ で、のついた物理量は、静忖：㥞流体のものからのずれ を表す。また、 $\epsilon_{i j}$ は战性芯力テンソル、 $\delta_{i}$ は lironecker の䛉揨である。

Curleの式は、式 $(5)$ において、c 0 を音速とし、目甘 空閆でのグリーン関数を道用して得られる。物体が㴊 体で移動しない場合、Curleの式(2)は、

$$
\begin{aligned}
p^{\prime}= & \frac{1}{4 \pi} \frac{\partial^{2}}{\partial x_{i} \partial x_{j}} \int \frac{T_{i j}\left(\mathbf{y}, t-r / c_{0}\right)}{r} d V \\
& -\frac{1}{4 \pi} \frac{\partial}{\partial x_{i}} \int \frac{f_{i}\left(\mathbf{y}, t-r / c_{0}\right)}{r} d S
\end{aligned}
$$

となる。ここで、 $x, y$ はそれそれれ観測点と音源の位置べ クトル、rは観測点と音源との距離 $|\mathrm{x}-\mathrm{y}| 、 f_{\mathrm{i}}$ は物体境 界に衔く単位面皘あたりの力を示す。また、dV，dSはそ れぞれ体積要素、佰皘要素である。

音源領域がコンパクトな場合には、式(7)の空間微 分を時閌微竹に置き换えることができる。また、一般 に、流れのマッハ数が小さいときには、第 2 項に比べ て第1 項は小さくなる。さらに、物体表面位置の違い による遅延時間差を無視すると、式（7）は、

$$
p^{\prime}=-\frac{x_{i}}{4 \pi c_{0} x^{2}} \int \frac{\partial f_{i}\left(\mathbf{y}, t-x / c_{0}\right)}{\partial t} d S
$$

と簡㱖化することができる。式 (7) から式 (8) を導くの に用いた条件は、ここで扱うようなカルマン佩から放 射される音の場合には満足されている。

2.3 Howe の式 Howeは、Lighthill 万程式に対 㚇する対流波動方程式を導いた。マッ八数が小さく熱 の移動が無視できる流机の場合、淀み点エンタルピー Bについての対流波動方程式 ${ }^{(5)}$ は、

$$
\left\{\frac{1}{c_{0}}\left(\frac{\partial}{\partial t}-\mathbf{U} \cdot \nabla\right)^{2}-\nabla^{2}\right\} B=\nabla \cdot(\boldsymbol{\omega} \times \mathbf{u})
$$

となる。ここで、Uは一样流の速度ベクトル、山は佩 度ベクトルである。

物体表面での境界条件を近似的に渵足する低周波数 グリーン関数を用いた式 (9)の近似解析解において、 式 (7) から式 (8) を晸いたのと同様の条件を適用した上 で、一様流のマッ八数が 0 の極限を考えると、

$$
\begin{aligned}
p^{\prime} & =-\frac{\rho_{0}}{4 \pi c_{0} x} \frac{\partial}{\partial t} \int\left\{(\boldsymbol{\omega} \times \mathbf{u}) \cdot \nabla_{y}\left(\frac{x_{i} Y_{i}}{x}\right)\right\} d V \\
& =-\frac{x_{i}}{4 \pi c_{0} x^{2}} \int \frac{\partial}{\partial t} \rho_{0}\left\{(\boldsymbol{\omega} \times \mathbf{u}) \cdot \nabla_{y}\right\} Y_{i} d V
\end{aligned}
$$

が導かれる。ここで、Y低低周波グリーン関数の一部 であり、i方向から速さ1の仮想的な一様流がくるとき の、物体まわりの速度ポテンシャルを表す(9)。直径 $d$ の 円柱の場合、 


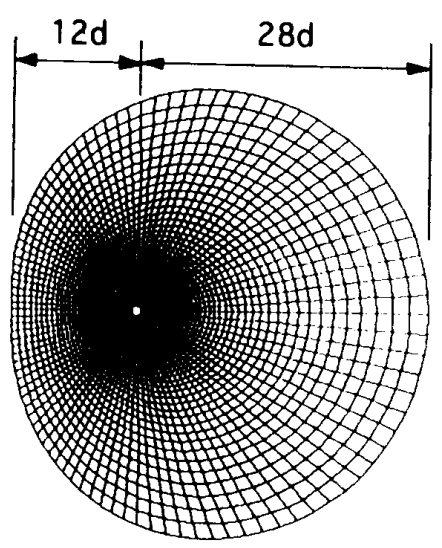

Fig. 1 Grid system

$$
\left(\begin{array}{c}
Y_{1} \\
Y_{2} \\
Y_{3}
\end{array}\right)=\left(\begin{array}{c}
\left\{1+d^{2} / 4 y^{2}\right\} y_{1} \\
\left\{1+d^{2} / 4 y^{2}\right\} y_{2} \\
y_{3}
\end{array}\right), y^{2}=y_{1}^{2}+y_{2}^{2}
$$

である。

\section{3. 解析結果}

3.1 CFD 解析 円柱のまわりのレイノルズ数 $10^{3}$ の流れを対象として 2 次元解析を行った。一様流の速 度 $U$ と円柱直径 $d$ を用いて $d / U て ゙$ 無次元化した時間刻

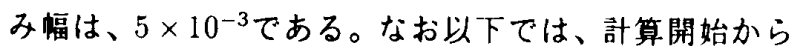
䄪 95 無次元時間が経過し、流れが十分周期的になった と考えられる時点を、時刻 0 とする。

図 1は、数値解析に使用した格子である。O型で格子 点数は、周方向、半径方向にそれそれ 100 点、計 10,000 点である。解析領域は、ほぼ円形（半径 $20 d$ ) であり、 円柱は領域の中心から $8 d$ ほど上流側にある。この格子 系で解析を行うため、式 (1) と式 (2) を一般座標変換し て解析した。

図 2は、揚力係数 $C_{L}$ と抗力係数 $C_{D}$ の時間変化の梯 子である。 $C_{L} 、 C_{D}$ とに、正弦波状の変化をしてお り、カルマン渦が周期的に放出されている様子がうか がえる。

抗力係数の平均値は 1.47 であり、このレイノルズ数

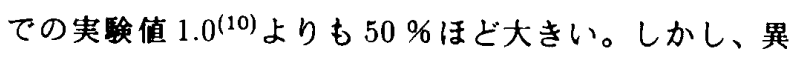
なる格子で行った予備計算でも同じ值が得られており、 このことの原因は、2次元解析を行っているということ にあるものと考えられる。すなわち、円柱後方の剥離 現象が実際の 3 次元の現象に比へて強くなっているこ 亡と、実際の現象では円柱の長手方向に剥離現象の位 相のずれが生じていることが原因としておげられる。

表 1に、揚力係数と抗力係数の平均值と振幅、図 2 から読みとった Strouhal 数の值を示す。また、著者ら

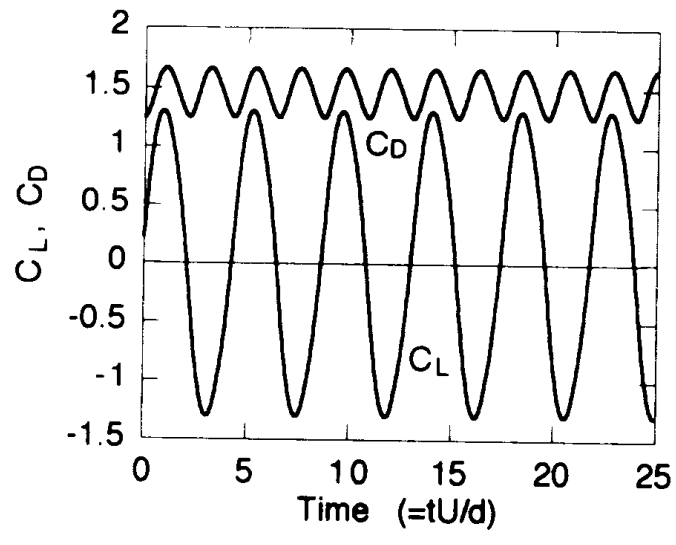

Fig. 2 Time history of $C_{L}, C_{D}$

Table 1 Lift and drag coefficients $\left(C_{L}, C_{D}\right)$, Strouhal number $(S t)$

\begin{tabular}{cl|c|c}
\hline & & Present & Ref.(11) \\
\hline$C_{L}$ & mean & 0.0 & 0.0 \\
& amplitude & 1.30 & 1.4 \\
\hline$C_{D}$ & mean & 1.47 & 1.5 \\
& amplitude & 0.21 & 0.2 \\
\hline \multicolumn{2}{c|}{$S t$} & 0.23 & 0.24 \\
\hline
\end{tabular}

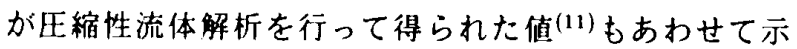
す。本解析の結果亡IE縮性流体解析の結果は、非常に よく一致しており、実呀值との差異はあるものの、流 れの 2 次元数值解析としては、妥当な結果が得られて いるものと考えられる。

3.2 流体音の解析 Curleの式とHoweの式の雨 者を用いて流体音の解析を行った。ここでは、図3に示 すように座標系を定め、 $x_{1}$ を流れに沿った方向、 $x_{2}$ を 流れに垂直な方向とする。

3 次元 CFD 解析の紹果を用いる場合には、四柱長手 方向の流れの位相差を考虑できる(3)が、2 次元 CFD 解

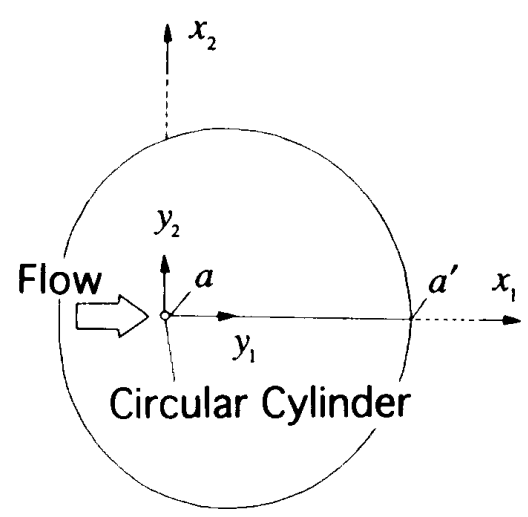

Fig. 3 Geometry of interest and computational domain 
析の結果を用いる場合、実験もしくは 3 次元 CFD 解析 から得られる長手方向の相関長さを与える必要がある。 しかし、相関長さの確たる値は明らかでなく、流体音 の大きさと相関長さは単純な比例関係にあるので、こ こでは円柱直径を代表長さに選び、円柱長さを直径と 同じとする。また、円柱端面の影䈏は無視する。

Curleの式と Howeの式は、観測点の位置ベクトル x と音源を表す項 $\mathbf{Q}$ の内皘の形をしている。それそれの 式に対してQを、

$$
\begin{aligned}
& Q_{i}=\int \frac{\partial f_{i}}{\partial t} d S \quad \text { (Curle) } \\
& Q_{i}=\int \frac{\partial}{\partial t} \rho_{0}\left\{(\boldsymbol{\omega} \times \mathbf{u}) \cdot \nabla_{y}\right\} Y_{i} d V(\text { Howe })
\end{aligned}
$$

と定義する。式 (12) と(13)の両式に、CFD解析で得ら れた $f_{i} お よ ひ ゙ \omega, \mathbf{u}$ を代入して求めた $Q$, の時間変化を図 4 に示す。 $Q_{i}$ を求める際の体積積分と時間微分は数值的 に行った。また、図4の繸軸は、 $\rho_{0} U^{3} d て ゙$ 無次元化して 示してある。最大、最小となる部分で若千の差異がみ られるものの、Curleの式による $Q_{i}$ と Howe の式による Q は音场の指向性を表しているので、雨者が $Q_{1} 、 Q_{2}$ とも に一致していることから、放射される音の振幅と指向 性のどちらもよく合っていることがわかる。

Lighthill 方程式 (5)、Howe の波動方程式 (9) におい て、音波が微少変動であるという近似をあらかじめ䢘 入すると、それぞれ

$$
\begin{aligned}
& \left(\frac{1}{c_{0}^{2}} \frac{\partial^{2}}{\partial t^{2}}-\nabla^{2}\right) p^{\prime}=\frac{\partial^{2} T_{i j}}{\partial x_{i} \partial x_{j}} \\
& \left(\frac{1}{c_{0}^{2}} \frac{\partial^{2}}{\partial t^{2}}-\nabla^{2}\right) p^{\prime}=\rho_{0} \nabla \cdot(\boldsymbol{\omega} \times \mathbf{u})
\end{aligned}
$$

となる。一般に、マッハ数の小さい流れでは、 $T_{i j} \simeq$ $\rho_{0} u_{i} u_{j}$ と近似することができる(12)。また、

$$
\rho_{0} \frac{\partial^{2} u_{i} u_{j}}{\partial x_{i} \partial x_{j}}=\rho_{0} \nabla \cdot(\boldsymbol{\omega} \times \mathbf{u})+\rho_{0} \nabla^{2}\left(\frac{u^{2}}{2}\right)
$$

なので、式 (14) と式 (15) の差異は、 $\rho_{0} \nabla^{2}\left(u^{2} / 2\right)$ の関与 する部分である。(Howeの波動方程式 (9) は淀み点工 ンタルピーBについて導かれているため、この部分は 左刃に含まれている。)

この部分の影第について調へるため、Howeの式を用 いたQ、において時間微分を除いた

$$
\begin{aligned}
& s_{i}^{0}=\int \rho_{0}\left\{(\boldsymbol{\omega} \times \mathbf{u}) \cdot \nabla_{y}\right\} Y_{i} d V \\
& s_{i}^{\text {add }}=\int \rho_{0}\left\{\left(\nabla \frac{u^{2}}{2}\right) \cdot \nabla_{y}\right\} Y_{i} d V
\end{aligned}
$$
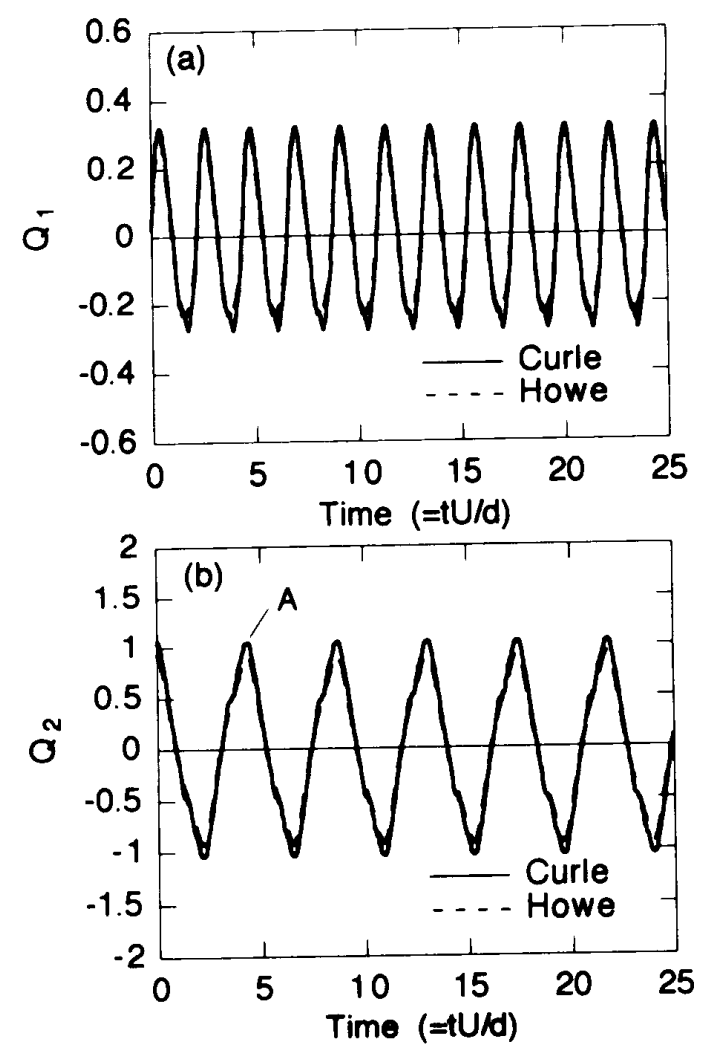

Fig. 4 Time history of $\mathbf{Q}:(\mathrm{a}) x_{1}$ component, (b) $x_{2}$ component

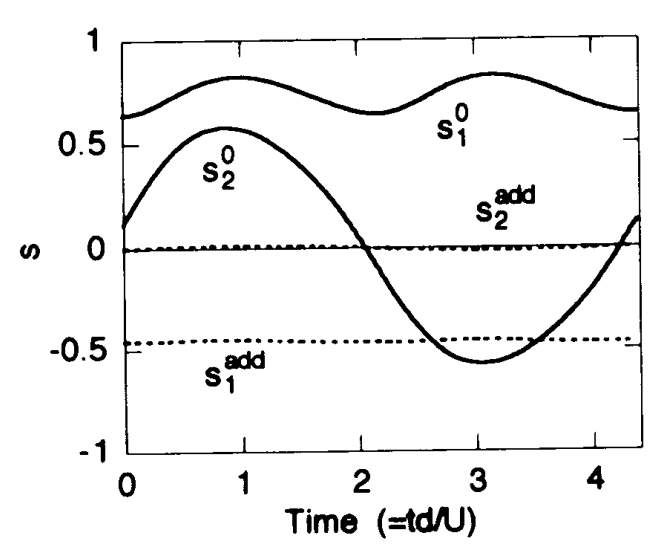

Fig. 5 Time history of $s$

を定義する。 $\rho_{0} U^{2} d^{2}$ で無次元化した $s_{i}^{0} 、 s_{i}^{\text {add }}$ の時間変化 を図 5に示す。 $s_{1}^{\text {add }}$ は䄪 $-0.45 、 s_{2}^{\text {add }}$ は約 0 でほぼ一定值 となっており、いすれも $s_{1}^{0} 、 s_{2}^{0}$ と比へると時間変化が

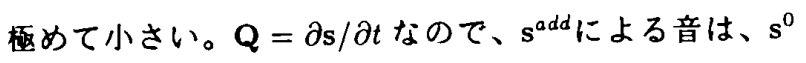
による音に比へて、ほぼ無視できる大きさになる。し たかっって、表面積分と体積棈分という解の表現の形式 は異なるが、音源の位置による位相差を無視した壹距 雄音場という近似を導入しても、Curleの式と Howeの 式は同等の值を与えることになる。

3.3 音場の㴍子 Curleの式とHoweの式は同等 の結果を与えることがわかったので、Curleの式を使っ 


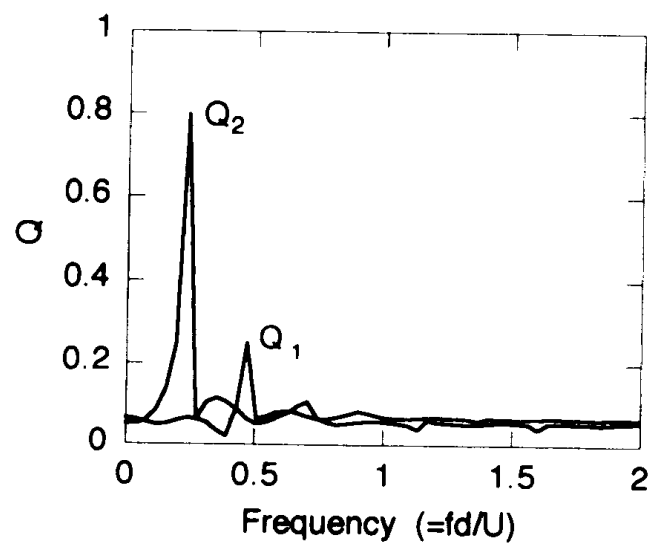

Fig. 6 Spectrum of $\mathbf{Q}$

て音場の様子を調べ。Curleの式によると、 $x_{2}$ 方向に 故射される音は円柱に動く揚力変動に对応し、 $x_{1}$ 方向 に放射される音は、抗力変動に対応する。今回行った C F D 解析結果は、前述のように実駼結果とは異なる ので、ここでは定性的な音場の様子を調へる。

図 4では、 $x_{2}$ 方向に放射される音の方が $x_{1}$ 方向に放 射される音よりも大きくなっている。これによって全 体の音場は、流れに垂直な力向に軸を持つ双極子的な ものになる。Qの周波数分析結果を図6に示す。横軸 は、 $U / d て ゙$ 無次元化した周波数であり、綎軸は $\rho_{0} U^{3} d て ゙$ 無次元化した $\mathrm{Q}$ の振幅である。 $x_{2}$ 成分の基本周波数は Strouhal 数、すなわち揚力変動の周波数に対応してお り、 $x_{1}$ 成分の基本周波数は抗力変動の周波数に対応し ている。

これらの定性的な音場の特徵は、実験やこれまでの 報告(6).(11)でも確認されている。

\section{4 音源領域 Curleの式では、物体表面を音源} とみなすのに対して、Howeの式では流れの中に音源領 域を考えている。ここでは、観測される音の大きい $x_{2}$ 方向の音を対象にして、Howeの式に基ついて音源領域 を調へる。

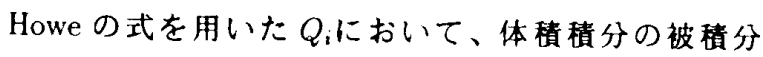
関数を式(19)のように定義する。

$$
q_{i}=\frac{\partial}{\partial t} \rho_{0}\left\{(\boldsymbol{\omega} \times \mathbf{u}) \cdot \nabla_{y}\right\} Y_{i}
$$

図7に、図3の $a a^{\prime}$ で示される線分に治った $q_{2}$ の分布 を、 $\rho_{0} U^{3} / d^{2}$ で無次元化して示す。横軸は $d$ で無次元化 してあり、 $y_{1}=0$ は、冈柱の中心である。内柱の後方 $y_{1}=d$ の付近で、振幅汃展大になり、网柱から10dほ ど離れると、振幅がほぼ0になっている。また、どの 時刻においても、正負の領域が交互に現れている。こ れらの符号の異なる領域から放射される音が互いに打 ち消し合った残り部分が㵶測される音となる。
線分 $a a^{\prime}$ :の分布のみを示しているため、図汭らだ けでは明らかでないが、解析領域全体を調てると、図 4の点Aで示されている時刻のように、 $Q_{2}$ が正（音の 欧汃が負）のときには、 $q_{2}$ の正の領域からの寄与が負 の領域からの奇与に比へて強くなっている。このとき、 $q_{2}$ が负の領域は音を小さくする働きをする。また、 $Q_{2}$ が負（音の压力が正）のときには、 $q_{2}$ の負の領域から の奇与が強くなっており、 $q_{2}$ が正の領域は音を小さく する働きをする。つまり、 $Q_{2}$ と $q_{2}$ の符号が同じ領域は、 音の聑力を大きくするのに寄与する正の音源領域であ り、檕者の符号が異なる領域は、負の音源領域だと考 えられる。そこで、任意の観測点の力向を考えて、

$$
E_{i j}=\frac{x_{i} q_{i}}{x} \frac{x_{j} Q_{j}}{x}=\frac{x_{i} x_{j}}{x^{2}} q_{i} \int q_{j} d V
$$

で表される $E_{i}$ を定義する。

図 8は、図3の $a a^{\prime}$ で示される線分に沿った $E_{22}$ の分布 を $\rho_{0}^{2} U^{6} / d て ゙$ 無次元化して示したものである。 $E_{22}$ は時 間变動しており、常に一定の寄与をする音源領域は存 在しない。また、時刻 2.175 と $4.375 に お い て 、 E_{22}$ は 一致してしている。これは、両時刻での $q_{2}$ が、どの位 置でも符号が逆で絶対值はほほ等しく（図 7)なってお り、 $Q_{2}$ の值も両時刻で符号が逆で絶対値がほぼ等しく (図4)なっていることによる。

この $E_{i}$ を用いる亡、音の正力の 2 乗平因値を

$$
\begin{aligned}
\overline{p^{\prime 2}} & =\frac{1}{16 \pi^{2} c_{0}^{2} x^{2}} \overline{\left(x_{i} \int q_{i} d V\right)^{2}} \\
& =\frac{1}{16 \pi^{2} c_{0}^{2} x^{2}} x_{i} x_{j} \overline{\int q_{i} d V \int q_{j} d V} \\
& =\frac{1}{16 \pi^{2} c_{0}^{2} x^{2}} x_{i} x_{j} \overline{\int q_{i} \int q_{j} d V d V} \\
& =\frac{1}{16 \pi^{2} c_{0}^{2}} \int \frac{\overline{x_{i} x_{j}}}{x^{2}} q_{i} \int q_{j} d V d V \\
& =\frac{1}{16 \pi^{2} c_{0}^{2}} \int \overline{E_{i j}} d V
\end{aligned}
$$

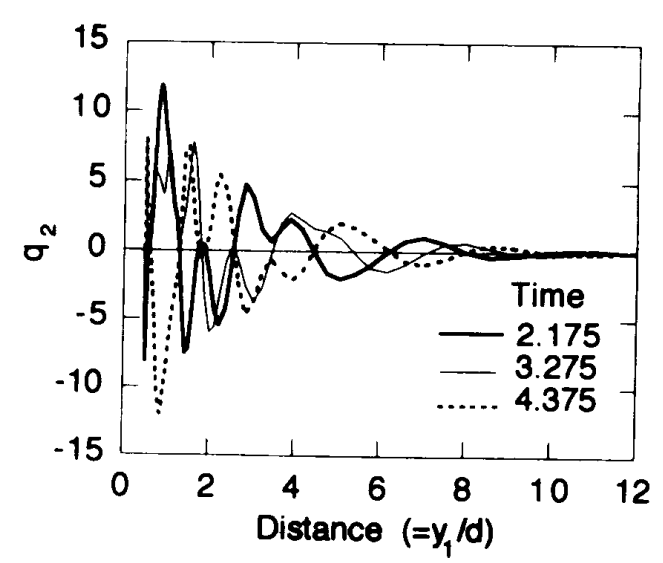

Fig. 7 Distribution of $q_{2}$ on $a a^{\prime}$ 


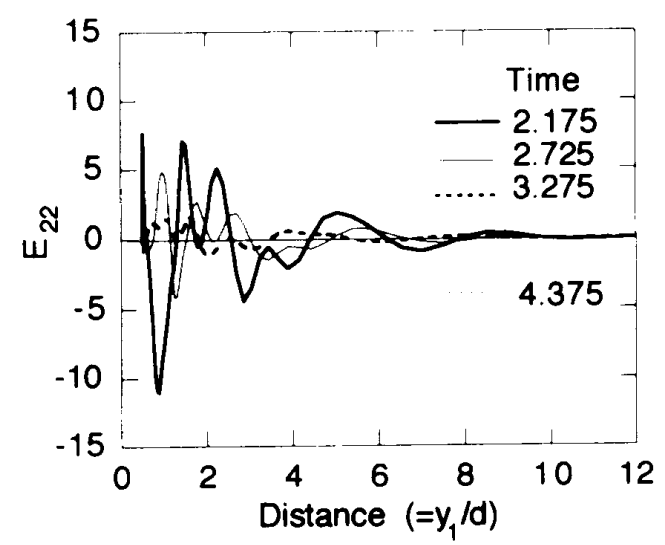

Fig. 8 Distribution of $E_{22}$ on $a a^{\prime}$

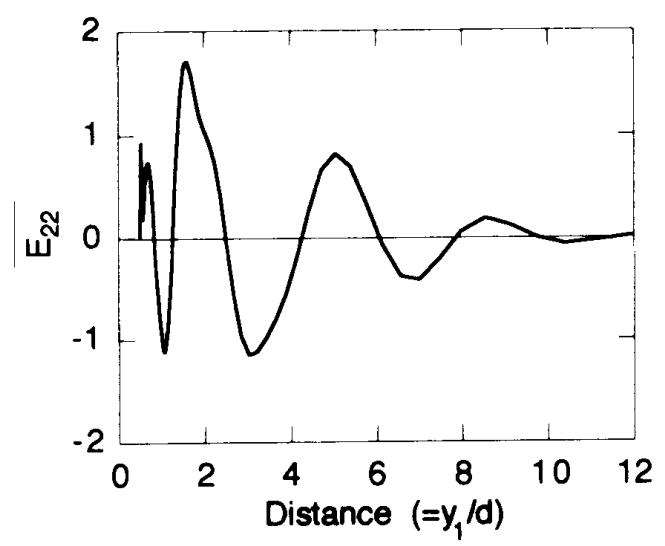

Fig. 9 Distribution of $\overline{E_{22}}$ on $a a^{\prime}$

と表すことができる。ただし、一は、時間平均を表す。 したかっって、尉は、Curleの式を用いて定義された物 体表面上の相当音源強度(4),(13)に対応する、2 乗平均音 压に対する流れ領域の中の相当音源とみなすことがで きる。

図 9に、 $\rho_{0}^{2} U^{6} / d$ で無次元化した $\overline{E_{22}}$ の分布を示す。時 間平均は、数值皘分によって求めた。 $\overline{E_{22}}$ は一様にはな らず、正負の相当音源領域が入り組んで現れる。すな わち、観測される音に対して時間平均的に正の奇与を する部分があり、逆に負の寄与をする部分も存在する。 図 9では、観測される音に正の奇与をする相当音源領 域か、 $y_{1}=2 d$ の付近にあり、負の寄与をする領域が、 $y_{1}=d, 3 d$ の付近にあることがわかる。正の相当音源領 域の位置は、図7に示す $q_{2}$ の振幅の大きい位置とは一 致しない。このような場合、 $q_{2}$ の振幅のみで音源領域 を決めるのは困難であり、 $\overline{E_{22}} E_{22}$ を用いるのが道当 であると考えられる。

解析領域内の $\overline{E_{22}}$ の分布を、図10に示す。図 $10(\mathrm{a})$ は 正の相当音源分布図であり、図 $10(\mathrm{~b})$ は負の相当音源 分布図である。図9で調へた円柱後方の領域以外に、円 柱の上下にも強い相当音源が分布しており、負の相当 音源の領域を取り囲むように正の相当音源が広がって

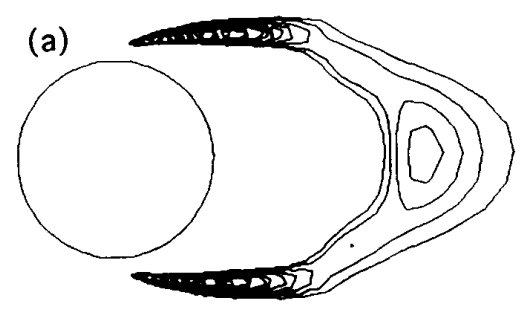

(b)
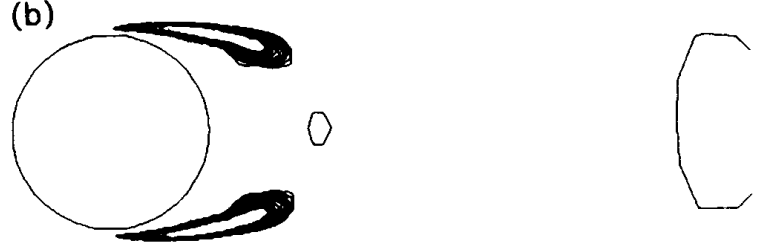

Fig. 10 Distribution of $\overline{E_{22}}:(a)+1 \sim+3$, (b) $-3 \sim-1:$ The interbals of lines are 0.2 .

いる。もっとも強い正の相当音源領域は、円柱の上下 の強い剪断層の你在する領域だと推测されるが、現在 のところ、流れ場と直接の対忍付けをするには到って いない。

\section{4. 結 言}

一样流中の円柱まわりの流れの 2 次元解析結果に、 Curleの式あるいはHoweの式を組み合わせて、流体音 の解析を行い、以下の結論を得た。

(1) 音の王力を表面積分で表すCurleの式と体積皘分 で表す Howeの式は、遠距離音場に対して同等の結果 を与える。

(2) 円柱から放射される流体音は流れに莗直な方向 に指向性をもつ双極子的なものとなる。これは、Curle の式から導かれるように、放射される音が、円柱に㗢 く力の時間微分で評価でき、揚力変動の方が抗力変動 よりも大きいことによる。

(3) 流れの中には、正負の異なった符号をもつ音源領 域が入り組んでおり、そ拈が相殺したわずかな残り の部分が観测される音となる。

(4) Howeの式により、流体内部の相当音源強度の分 布を調へることができる。相当音源強度が時間平均的 に正になる領域、目になる領域が存在する。

今回の解析では、流れの 2 次元数值解析の結果を用 いているため、定量的なことまで調へることはできな かったか、流れの 3 次元解析の結果とHoweの式を組み 合わせることにより、流れの制御による流体音の制御 のための相当音源の情報が得られるものと考えられる。

\section{文献}

(1) Lighthill, M. J., Proc.Roy.Soc.London, Ser.A 211 (1952), 564 . 
(2) Curle, N., Proc.Roy.Soc.London, Ser.A 231 (1955), 505 .

（3）加藤・ほか 4 名，譏論， 60, B(1994), 126.

(4) 三宅・ほか 3名，裁論, 59, B(1993), 3475.

(5) Howe, M. S., J. Fluid. Mech., 71(1975), 625.

(6) Hardin, J. C. and Lamkin, S. L., AIAA J., 22-1(1984), 51.

(7) Kambe, T., J. Fluid. Mech,, 173(1986), 643.

(8) Tamura, T. and Kuwahara, K., AIAA Paper, 89 1805(1989).

(9) Howe, M. S., J. Fluid. Mech., 67(1975), 597.

（10）日本流体力学会絧, 流体力学ハンドブック, 丸善 (1987), 232.

（11）古池・ほか 2 名，川崎重工技報,116(1993), 14.

(12) Goldstein, M. E., AEROACOUSTICS, MacGRAWHILL International Book Company(1976),71.

(13) 丸田・小竹，诫論, 46, B(1980), 1055. 